\title{
How does Cognitive Behavior Therapy view an Academic Anxiety of the Undergraduate Thesis?
}

\author{
Dominikus David Biondi Situmorang \\ Universitas Katolik Indonesia Atma Jaya, Indonesia \\ david.biondi@atmajaya.ac.id
}

Article Information:

Received: February 21, 2018

Revised: May 31, 2018

Accepted: July 12, 2018

\section{Keywords:}

cognitive behavior therapy, academic anxiety, undergraduate thesis, millennials college students.

\begin{abstract}
The undergraduate thesis is still a terrifying final project for most millennials college students. Many of them are procrastinating, avoiding their supervisors, doing non-productive things as a form of anxiety diversion, and the most extreme is to committing suicide as a result of excessive academic anxiety. The educational counselors as one of the college internal agents is expected to solve the problems that often occured. Based on Cognitive Behavior Therapy (CBT) approach, the academic anxiety of the undergraduate thesis experienced by millennials college students is a cognitive distortion caused by maladaptive core beliefs. Therefore, what we need to know more about how CBT view an academic anxiety of the undergraduate thesis as a problem, so that counselors in Indonesia will be able to understand conceptually before do practice of healing counseling to help the millennials college students to be free from this problem in the future. This research uses descriptive analysis and Focus Group Discussion (FGD) approach. The result of this research is CBT-Based Music can help millennials college students to restore cognitive, affective, and behavioral functions to be adaptive again, so millennials college students are expected to independently optimize their potential, in order to reduce academic anxiety and solve the undergraduate thesis well.
\end{abstract}

\section{INTRODUCTION}

The college students before getting their academic degree, must compose a scientific paper called the undergraduate thesis. The undergraduate thesis is a paper that represents a certain scientific understanding that can be accounted scientifically (Sudarnoto, Pedhu, Mamahit, Prasetiyo, 2012). As a paper containing scientific content, in the process of making of it, the undergraduate thesis must meet the rules of scientific writing related to content, systematic writing, and writing techniques. In addition through research activities, the undergraduate thesis can also be born from a literature review process, which aims to answer various scientific problems through a systematic method (Sudarnoto et al., 2012).

Most of the millennials college students in Indonesia consider that the undergraduate thesis is a quite difficult as final project (Situmorang, 2017a, 2017b, 2018a, 2018b, 2018c; Situmorang, Mulawarman, Wibowo, 2018). Based on the results of existing studies and research, the cause of high anxiety towards undergraduate thesis is due to the low skill possessed by college students to write, and they have a low interest in their research. Furthermore, other research results show that low of achievement motivation and creativity is another predictor that causes of academic anxiety (Situmorang, 2015, 2016). Based on the foregoing, quite a lot of millennials college students are doing procrastination, avoiding their supervisors, doing unproductive things, and the most extreme is committing to suicide

How to cite :

E-ISSN:

Published by:

Available online:
Situmorang, D. D. B. (2018). How does cognitive behavior therapy view an academic anxiety of the undergraduate thesis? Islamic Guidance and Counseling Journal, 1(2), 69-80. https://doi.org/10.25217/igcj.v1i2.221

2614-1566

Institut Agama Islam Ma'arif NU (IAIMNU) Metro Lampung

https://journal.iaimnumetrolampung.ac.id/index.php/igcj 
(Situmorang, 2017a, 2017b, 2018a, 2018b, 2018c; Situmorang, Mulawarman, Wibowo, 2018).

The things that happen to the millennials college students who make the undergraduate thesis are the symptoms of academic anxiety. Academic anxiety to the undergraduate thesis is an excessive anxiety about the final scientific task that is very disturbing attention, concentration, and welfare of life. Millennials college students who experience an academic anxiety will feel maladaptive in cognitive, affective, psychic, and behavior (Situmorang, 2017b, 2018a; Situmorang, Mulawarman, Wibowo, 2018).

Bandura (1997) provides an understanding that students who have high academic anxiety on the undergraduate thesis is caused by low self-efficacy. Self-efficacy is a student's belief about their capability to be able to finish their undergraduate thesis well (Purwanto, in Prawitasari, 2012). If students' self-efficacy is low, it will have an impact on increasing academic anxiety. Meanwhile, if students' self-efficacy is high, it will affect the reduction of intrusive thoughts, which indirectly will decrease the level of academic anxiety to the undergraduate thesis (Situmorang, 2017b, 2018a; Situmorang, Mulawarman, Wibowo, 2018).

The results of Csikszentmilhalyi's research (in Schunk, Pintrich, \& Mecce, 2014) conclude that there are two antecedents affecting students' affective responses to academic tasks, the first being the degree of challenge faced by the students, and the second degree of capability or skill possessed by students in completing academic task. Based on the two antecedents, students will experience three different affective responses, i.e. there are students who tend to experience boredom, there is also a tendency to experience anxiety, and some are likely to experience drift in the task (flow). Students who tend to experience boredom are those who have the view that their degree of capability is higher than the degree of challenge (difficulty task), on the contrary those who tend to experience anxiety are those who have the view that the degree of challenge (difficulty task) that they get beyond capability they have. While the students who experience drift in the task (flow) is for those who have the view that their degree of capability as large as the degree of challenge (difficulty task).

Furthermore, the approach of Cognitive Behavior Therapy (CBT) has a unique view of the problems experienced by students. CBT considers that students who experience academic anxiety to the undergraduate thesis is a cognitive distortion related to helplessness or inability in preparing the undergraduate thesis (Corey, 2013). Cognitive distortion if further examined sourced from the maladaptive core belief who have settled for so long in students. Core belief is the most basic belief about oneself that is influenced by past experiences. The existence of the belief that powerless, incapable, or not qualified in preparing the undergraduate thesis experienced by students affected by maladaptive core belief (Corey, 2013). These are the features of low self-efficacy (Bandura, 1997). So, to help students improve their self-efficacy and reduce their academic anxiety, what the counselor needs to do is to help students to restructure their negative thoughts to be more adaptive (Situmorang, 2017b, 2018a; Situmorang, Mulawarman, Wibowo, 2018).

In an effort to help students to restructure their negative thoughts, Corey (2012) states that in the implementation of CBT approach can use some existing counseling techniques, among others; cognitive restructuring, modeling, behavior building exercises, homework, feedback, desensitization, problem solving, stress management, information sharing, meditation and relaxation exercises (through music). Furthermore, music intervention as a technique in CBT is supported by several existing literature studies. Capuzzi and Gross (2012), and Sharf (2012), in an integrative approach study discussing the use of music that can be integrated in conventional counseling processes, this process is called music therapy. Furthermore, Gladding (2016) also provides an advanced understanding that the breakthrough counseling process is now turning to creative counseling that integrates with art therapy in its application. In the study, Gladding (2016) describes the use of music in counseling in the 
main section. Gladding (2016) strongly recommends the use of music in the counseling process, because music is universal medium, so it can penetrate cultural boundaries. Actually, everyone loves music, regardless of age, gender, religion, race, educational background, economy, and others (Djohan, 2006).

Further support is contained in the literature put forward by Wigram, Pedersen, and Bonde (2002), that the development of the application of music intervention in the world is largely centered on Behavior theory, which is more specifically aimed at Cognitive Behavior Therapy (CBT). This is supported by several recent studies related to music therapy based on CBT approach (Baker, Gleadhill, \& Dingle, 2007; Fredenburg \& Silverman, 2014; Giovagnoli, Oliveri, Schifano, \& Raglio, 2014; Gómez Gallego \& Gómez Garcia, 2017; Gomez-Romero et al., 2016; Hui-Chi Li et al., 2015; Rogers et al., 2007; Spahn, 2015; Stamoua et al., 2016; Vargas, 2015; Zhang et al., 2017). These studies have proven the effectiveness of music intervention that has been integrated with the CBT approach for individuals with dementia, Alzheimer's, drug addiction, and organ transplants. However, until now research in the education field is still very rare even difficult to find. It was only in 2018 for the first time in Indonesia, research on the integration of music therapy with CBT counseling in the field of education emerged. Situmorang (2018a) successfully tested the effectiveness of CBT group counseling using passive and active music therapy techniques, both of which effectively reduced the academic anxiety and increased the self-efficacy of millennials students.

\section{METHOD}

The nature of this research is descriptive analysis by describing systematically all the concepts that have relevance to the discussion. Then, the author analyzes the appropriate data were collected. This research uses Focus Group Discussion (FGD) approach with 14 respondents about an academic anxiety of the undergraduate thesis. The purpose of the FGD is to explore a specific problem related to the topic being discussed. This approach is used with the aim of avoiding the erroneous meaning of the author interpretations about the issues raised in this article. To analyze the obtained data, the author uses content analysis method. Content analysis method conducts a deep description of content, written information (Arikunto, 2006).

\section{RESULT AND DISCUSSION Academic Anxiety}

According to Cornell University (2007), academic anxiety is the result of a growing biochemical process in the body and brain that needs attention. Changes occur in response to academic situations, such as completing tasks at university, classroom discussions or exams. When anxiety increases, the body will react or respond to reject or fight for it. According to Ottens (1991), academic anxiety is a condition caused by excessive anxiety with the various academic tasks within the educational institution. When anxiety is felt by students is excessive it will negatively affect because students experience psychological pressure, so that students get less good learning results and more avoid the task. This is due to the decrease in attention span, concentration and memory of the students. But on the other hand, anxiety has a positive effect on students because it can motivate students to complete various academic tasks.

Further, Ottens (1991) and Cornell University (2007) describe the relationship between anxiety and student performance within the scope of education. If the lower (low) level of anxiety of a student, it will be lower (low) also level of performance in academic achievement. In addition, if the higher (level) of an anxiety of a student, it will be lower (low) also level of performance in academic achievement. However, if a student has a reasonable 
level of anxiety or leads to the middle level, it will tend to have a high level of performance (high). This proves that anxiety has a positive effect on students because it can motivate students to complete various academic tasks.

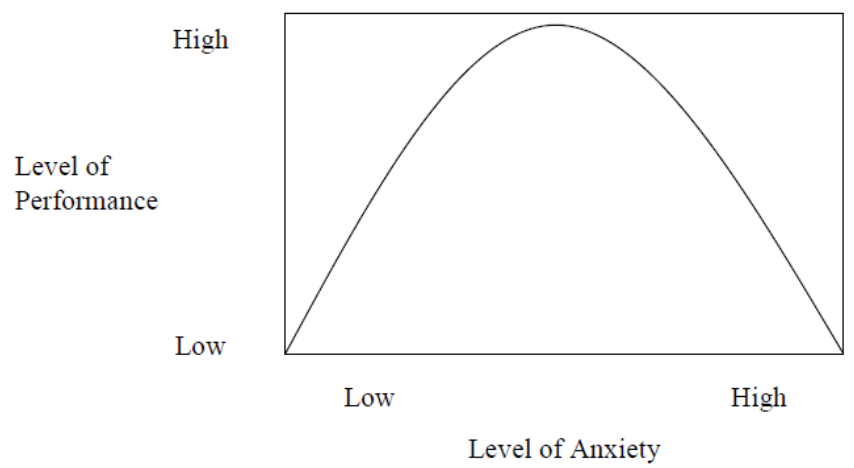

Picture 1. Relationship between anxiety and performance (Ottens, 1991; Cornell University, 2007)

\section{Characteristics of Academic Anxiety}

Situmorang (2018a) states that academic anxiety is an important issue that will affect a large number of learners. There are four characteristics of academic anxiety, e.g.: 1) Patterns of anxiety-engendering mental activity: Individuals show the thoughts, perceptions, and views that lead to academic difficulties to be faced. This involves three mental activities. First and most important is the concern. Individuals often feel insecure about what they do wrong. Second, academic anxiety is caused by a maladaptive self-dialogue. Self-dialogue in individuals with academic anxiety is often characterized by harsh self-criticism, self-criticism and self-talk panic that results in anxiety and contribute to undermining self-confidence and disrupting the individual within solution to problem. Third is the low self-esteem of the individual. Individuals have false beliefs about important issues that can lead to academic anxiety, such as how to establish self-worth, how to motivate yourself, and how to overcome anxiety, 2) Misdirected attention: This is a big problem in academic anxiety. In general, individuals are expected to concentrate fully on academic tasks, such as reading books, exams, and doing homework. However, individuals who experience academic anxiety let their attention diverge. Attention can be diverted through external factors (other learner's behavior, clock, noisy voices), or internal factors (anxiety, daydreaming, and physical reactions), 3) Physiological distress: Many changes in the body associated with emotions from anxiety become disrupted if interpreted as a dangerous thing or become the main focus of attention during academic tasks take place, 3) Inappropriate behaviors: Individuals experiencing academic anxiety choose behaviors that lead to inappropriate academic situations. Evasiveness (procrastination) is common, such as avoiding the task (talking with friends while studying). Individuals who are anxious also answer exam questions in a hurry or too careful to avoid mistakes in the exam. Another improper action is to force yourself when in a relax time.

\section{Cognitive Behavior Therapy (CBT) Approach}

Counseling based on CBT approach is an insight-focused counseling that emphasizes the process of changing negative thoughts and individualized maladaptive beliefs (Corey, 2013). The essence of the CBT approach is based on theoretical reasons for how people feel and behave, determined by how they perceive and structure their own experiences. The theoretical assumption of CBT counseling is that human internal communication is accessible to introspection, that counselee beliefs have a very personal meaning, and that this meaning can be found by the counselee of what the counselee is studying or interpreting. 
CBT counseling essentially aims to change the way maladaptive thinking of counselee by helping them realize automatic thought and cognitive distortion that comes from the core belief that has been settled. Then the thing that needs to be done is to help the individual to structure the negative thoughts that belong to the more adaptive thoughts. Individuals tend to defend their beliefs about themselves, their world, and their future. The main focus of CBT counseling is to assist counselees in testing and restructuring their core beliefs. By encouraging counselees to collect and consider evidence that supports their beliefs, counselors giving help to counselees to change their moods and behaviors (Corey, 2013).

\section{The Basic Aim of CBT Approach}

If a person often experiences maladaptive thoughts can cause stress or psychological disorders. The basic aim of CBT is to eliminate prejudice or cognitive distortion so that individuals can function more effectively. Cognitive distortions are challenged, tested, and discussed to bring more positive feelings, behaviors, and thoughts (Corey, 2013). Thus, when maladaptive thoughts often occur in individuals, the CBT approach is useful for seeking maladaptive thoughts and helping individuals understand the mistakes of thinking and making changes in the thinking of the counselees.

\section{Characteristics of CBT Group Counseling}

CBT has several unique characteristics that distinguish it from other approaches. It relies on the principles and procedures of the scientific method, and the experimental principles derived from systematic learning are applied to assist individuals in changing maladaptive behavior. According to Corey (2012), the distinctive characteristic that distinguishes it from other approaches is that CBT has systematic activities for specific purposes and evaluation. Concepts and procedures are explicitly stated, tested empirically, and are constantly being revised. Assessment and treatment occur simultaneously. The characteristics include:

Behavioral assessment. The behavioral assessment consists of a set of procedures used to obtain information that will guide the development of a specific treatment plan for each counselee and help measure the effectiveness of the treatment. According to Corey (2012), behavioral assessment involves five characteristics consistent with behavioral therapy; (1) behavioral assessment is aimed at collecting unique and detailed information about the counselee's problems, (2) focusing on the function and living conditions of the current counselee; (3) relating to sampling of counselee behavior to provide information about how counselees usually function in various situations, (4) a narrow focus rather than dealing with the personality of the counselee, and (5) integrated with therapy.

The main goal of counseling. The most unique aspect of CBT group counseling is regarding specific change objectives. CBT's approach to group counseling focuses more on specific destination areas of change than with other approaches. In CBT group counseling, the early stages of group work devoted to the counsel extend their assessment step by formulating specific statements of personal goals they wish to achieve. Identification goals determine the direction of the therapeutic movement. Although group leaders guide discussions and work with members, group members choose their personal goals (Corey, 2012). Group members describe the problematic behaviors they want to change and the new skills they want to learn. Counselees' personal goals may reduce anxiety in test situations, eliminate phobias that interfere with effective functioning, overcome depression, learn communication skills, develop problem-solving strategies to cope with the various situations encountered in everyday life, lose weight, and get rid of addiction (for smoking, alcohol, or other drugs). At the start of each session, the agenda is set to prioritize member goals and to explain how time will be used. This agenda was created by members and group leaders. A best CBT group is one that has a collaborative effort. 
Treatment plan. Once the members determine their goals, the treatment plan to achieve these goals is formulated. Behavior-oriented on cognitive behavioral techniques; members are expected to take an active role with the task, not just being passive and just talking about their own problems. Initially, group leaders generally develop a collaborative plan that includes every member of the group. After the initial assessment is undertaken, the group participants together with the group leader establish an intervention strategy that may be used. Ultimately, the person with the problem is the determinant of the strategy or action to take. Some of the most commonly used techniques are modeling, formation, behavior training, coaching, work, feedback, cognitive restructuring, desensitization, problem solving, meditation, relaxation exercises (through music), stress management, and information delivery.

Goal evaluation. Once the behavioral objectives have been clearly identified, specific treatment goals, and therapeutic procedures are described, the therapeutic results can be objectively assessed. Because the CBT group emphasizes the importance of evaluating the effectiveness of the techniques they use, the assessment of counselee progress toward their own goals. If the group meets for 10 weeks for social skills training, for example, basic data on these skills is likely to be taken in the initial session. At each subsequent session an assessment of behavioral change can be made so that members can determine how the success rate has been met. Providing members with feedback is an important part of this CBT group counseling.

The decision to use certain techniques based on their effectiveness. The range of these techniques is quite extensive, and many CBT group counseling practitioners are very eclectic in their choice of treatment procedures. They are willing to draw techniques from many therapeutic approaches in helping their members change their thinking patterns, feelings, and behaviors.

\section{Assumptions of the Academic Anxiety Problem according to CBT}

Based on the basic concepts related to academic anxiety that have been described previously, that academic anxiety is a subjective assessment or individual attitude about thoughts, perceptions, and views that lead to academic difficulties to be faced. Individual assessment of academic difficulties based on experience or events, when individuals are exposed to past events or experiences, will affect the way individuals deal with problems, including thinking, feelings, behaviors, and emerging body reactions. So it takes an approach that looks at the individual problem of how the individual thinks, feels, and behaves towards his body. The right approach is the behavioral cognitive approach (CBT).

According to Situmorang $(2017 \mathrm{~b} ; 2018 \mathrm{a})$, the behavioral cognitive model (CBT) consists of a hierarchy of thoughts divided into three main parts: (a) Negative Automatic Thoughts (NATs): thoughts that arise automatically, quickly, and unconsciously from within the mind when a person is experiencing stress or negative emotions associated with academic difficulties that will be encountered, such as the thought of "the undergraduate thesis is difficult", "the undergraduate thesis is a scary thing", etc., then (b) The basic assumption is the underlying assumption and guide the behavior of the individual day-to-day, set standards, life values, and rules for life. Next is (c) Core belief, is the most basic belief about self, the belief that academically incapacity and powerless beliefs. The individual's belief in powerlessness is like, "I can not afford to do the undergraduate thesis because my academic ability is less qualified", "I do not have good writing skills", etc. It is this core belief that has persisted and can lead to cognitive distortion, a condition that characterizes depressive thoughts about academic difficulties to be faced, so that individuals experience problems and have a certain picture of the problem.

Based on the above statements, it can be concluded that when an individual has an academic anxiety it will result in emotional disturbances such as: not confident, anxiety, depression, etc. The condition that characterizes this depressive mind arises because of 
cognitive distortions or negative thoughts relating to helplessness or incapacity in academics. Cognitive distortions are formed from the core beliefs that have settled that is the most basic beliefs about self, the existence of academically incapacity and helpless beliefs, these beliefs are formed based on experience or events experienced by individuals. Thus, when individuals experience problems related to academic anxiety, then the thing that needs to be done is to help the individual structure the negative thoughts back to more adaptive thoughts. The following is a form of adaptation of the concept of "Hot Cross Bun" (HCB) and CBT for Academic Anxiety (Situmorang, 2017b; 2018a):

\section{The Past Experiences}

For example: Experiencing academic failure (such as not going to high level of class, or getting bad grades), getting labeled as a child who is less intelligent from the environment as a child, the demands of parents for academic value is too high.

\section{Core Belief}

For example: "I can not do the undergraduate thesis because my academic ability is less qualified", "I do not have good writing skills", "I find it difficult to write undergraduate thesis well because I am not clever", "I am a fool or helpless child", etc.

\section{Cognitive Distortion}

For example: "If I am smart, I will be able to do undergraduate thesis well", "but if I am stupid, I will not be able to do undergraduate thesis well", "My parents think that I am a person who is helpless or stupid then others will do same thing "," my writing ability is bad, it indicates that I can not write undergraduate thesis well ".

\section{Triggers (Events and Situations)}

For example: Undergraduate thesis is a final task that is time-consuming, energy, and mind; quite a lot of students who consider undergraduate thesis as a scary thing, news media reported many suicide cases occurred in students thesis compilers, the amount of undergraduate thesis credit is so large that demanded to get an ideal value so as not to interfere with GPA, get negative label from others if not can pass on time.

\section{Automatic Thought}

For example: "I am stupid or helpless," I can not make a undergraduate thesis well because I am stupid "," my writing skills are not good "," I am not as smart as my friend ".

Body Reactions

Heart pounding hard, insomnia, groggy, trembling, etc.

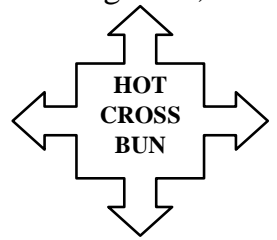

Behavior

\section{Affective}

Dissatisfaction with academic ability, low self-esteem, not confident with ability, anxiety and fear of failure, anxious can not pass the study

Procrastination, avoidance of lecturers, and do non-productive activities

$\underline{\text { Result }}$

High academic anxiety, low self-efficacy

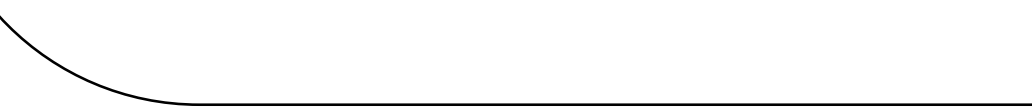

Picture 2. Hot Cross Bun and CBT for Anxiety 
A B C Model for Academic Anxiety based on CBT Approach

Basic Formula:

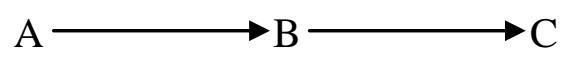

Picture 3. Model for academic anxiety based on CBT Approach

\section{A (Activating Event)}

One situation where that causes an unpleasant event, the originator may be from the environment or any stimulus that initiates the entire reaction process.

\section{B (Belief)}

Thoughts, beliefs, or attitudes.

\section{c (Consequence)}

The emotion or behavior of a person. $\mathrm{C}$ is a consequence of $\mathrm{A}$. Where they reflect in their feelings and thoughts.

\begin{tabular}{|c|c|c|c|}
\hline A (Activating Event) & B (Belief) & $\begin{array}{c}\mathrm{C} \text { (Consequence - } \\
\text { Emotional })\end{array}$ & $\begin{array}{c}\text { C (Consequence - } \\
\text { Behavior) }\end{array}$ \\
\hline $\begin{array}{l}\text { Undergraduate thesis } \\
\text { is enough to spend } \\
\text { time, energy, and } \\
\text { mind. }\end{array}$ & $\begin{array}{l}\text { "I can not do the } \\
\text { thesis because my } \\
\text { academic ability is } \\
\text { less qualified." } \\
\text { "I do not have good } \\
\text { writing skills." } \\
\text { "I'm not as smart as } \\
\text { my friend." }\end{array}$ & $\begin{array}{l}\text { - Dissatisfaction with } \\
\text { academic ability. } \\
\text { - Low self-esteem. } \\
\text { - Not confident with } \\
\text { personal abilities. } \\
\text { - Anxious. } \\
\text { - Fear of failure. } \\
\text { - Fear of not being } \\
\text { able to pass on } \\
\text { time. }\end{array}$ & $\begin{array}{l}\text {-Procrastination. } \\
\text {-Avoiding } \\
\text { supervisors. } \\
\text {-Conducting non- } \\
\text { productive } \\
\text { activities. } \\
\text {-If a person have } \\
\text { prolonged } \\
\text { depression it will } \\
\text { lead to suicide. }\end{array}$ \\
\hline & $\begin{array}{l}\text { "I'm confused where } \\
\text { to start." }\end{array}$ & & \\
\hline
\end{tabular}

Table 1. Clinical illustration of ABC model

\section{Effectiveness of CBT-Based Music to reducing the Academic Anxiety of Millennials}

Research on the provision of conventional counseling services to reduce academic anxiety proved less effective. The first research conducted by Zarei, Fini and khajehzadeh Fini (2010) against millennials college students at the University of Hormozgan, Iran, proved less effective in reducing their academic anxiety. Further research was conducted by Ghasemzadeh (2011), regarding the provision of group counseling services with SMC: Systematic Motivational Counseling which proved less significant in reducing academic anxiety.

Vianna, Barbosa, Carvalhaes, and Cunha (2012) suggest that the cause of anxiety is due to the high production of the hormone thyroxine in the human brain. This is what causes the individual easily tired, easily anxious, easily tense, easily afraid, and insomnia, so that individual circumstances become less optimal. To overcome the problem, one must be able to balance themselves in every condition experienced. The human brain has four natural morphine of the body, a positive hormone that can alleviate illness and make life happy. These morphines are endorphins, dopamine, serotonin, and oxytocin. The function of these morphines is that they can make the body more relaxed, reduce anxiety or stress (Mucci \& Mucci, 2002). One of the interventions to increase the production of endorphin and serotonin 
hormones is by listening to music (Laura et al., 2015; Wigram et al., 2002; Zarate, 2016). Psychologically, music has a positive relationship in human life. Music can make a person more relaxed, reduce stress, create a sense of security, increase happiness, increase intelligence, increase confidence, and help release pain (Djohan, 2006).

Based on the results of previous research, music as an intervention that can be done in helping a person in reducing anxiety has been proven (Lilley et al., 2014; Sharma \& Jagdev, 2012). The use of music can also be given in the counseling process. Through music, counselors can make the counseling process more interesting and effective, this is in accordance with the needs of the millennial generation (Skudrzyk, 2014). One technique that can assist counselors and counselors in reorganizing ideas, focusing perspectives, emotional externalization, and deepening understanding of experiences or problems is through music (Bradley et al., 2014). Music can be used as a counseling strategy in the form of relaxation techniques to reduce and overcome anxiety (Gladding, 2016; Gladding et al., 2015).

Basically, the application of music therapy is still rare because it is still new, especially in counseling. From the results of a meta-analysis study conducted by Dewi (2015), it is suggested that music can be used as an approach in helping individuals who experience physical, behavioral, and psychological barriers to be better. Research on the influence of music as a medium of therapy on academic anxiety of millennials students has also been done (Rosanty, 2014). From the results of that study, music can be used as an intervention to reduce the academic anxiety experienced by students who make undergraduate thesis. However, this study only proves the use of Mozart music as passive music therapy, and has not studied about providing music in active music therapy techniques.

It was only in 2018, the first study in Indonesia on the application of music therapy in integrated counseling practice using the CBT approach (Situmorang, 2018a). This study compares both passive and active music therapy. The results show that the integration of CBT group counseling with music therapy has proved effective in reducing academic anxiety and improving self-efficacy for millennials students. Furthermore, the results of this study prove that CBT group counseling with active music therapy techniques is the most effective technique in reducing academic anxiety and improving self-efficacy of millennials students, compared with passive music therapy.

\section{CONCLUSION}

Based on the above description, it can be concluded that the academic anxiety experienced by millennials students is a cognitive distortion caused by maladaptive core beliefs. Educational counselors or psychologists may conduct counseling services with CBTBased Music to assist millennials students in restoring cognitive, affective, and behavioral functions to be adaptive again. It is hoped that after the intervention, millennials students can independently optimize their potential to reduce their academic anxiety and they can complete the undergraduate thesis well. This review can be an interesting topic for follow-up in on-theground practice or for further research.

\section{REFERENCE}

Arikunto, S. (2006). Prosedur penelitian: Suatu pendekatan praktik. Jakarta: Rineka Cipta.

Bandura, A. (1997). Self-efficacy: The exercise of control. New York: WH. Freeman.

Baker, F. A., Gleadhill, L. M., Dingle, G. A. (2007). Music therapy and emotional exploration: Exposing substance abuse clients to the experiences of non-drug-induced emotions. The Arts in Psychotherapy, 34, 321-330. http://dx.doi.org/10.1016/j.aip.2007.04.005 
Bradley, L. J., Whiting, P., Hendricks, B., Parr, G., \& Jones Jr, E. G. (2014). The use of expressive techniques in counseling. Journal of Creativity in Mental Health, 3(1), 4459.

Capuzzi, D., \& Gross, D. R. (2011). Counseling and psychotherapy: Theories and intervention (5th ed.). New Jersey: Merril Prentice Hall.

Corey, G. (2012). Theory and practice of group counseling (8th ed.). American Board of Professional Psychology: Brooks/Cole.

Corey, G. (2013). Theory and practice of counseling and psychotherapy (9th ed). California: Brooks/Cole.

Cornell University. (2007). Understanding academic anxiety. USA: Cornell University.

Dewi, M. P. (2015). Studi metaanalisis: Musik untuk menurunkan stres. Jurnal Psikologi, $36(2), 106-115$.

Djohan. (2006). Terapi musik teori dan aplikasi. Yogyakarta: Galang Press.

Fredenburg, H. A., Silverman, M. J. (2014). Psychotherapy effects of cognitive-behavioral music therapy on fatigue in patients in a blood and marrow transplantation unit: A mixed-method pilot study. The Arts in Psychotherapy, 41, 433-444. http://dx.doi.org/10.1016/j.aip.2014.09.002

Ghasemzadeh, A. (2011). Effects of group "systematic motivational counseling" (SMC) on university student's academic achievement and test anxiety. Procedia-Social and Behavioral Sciences, 30, 2482-2486.

Giovagnoli, A. R., Oliveri, S., Schifano, L., \& Raglio, A. (2014). Active music therapy improves cognition and behaviour in chronic vascular encephalopathy: A case report. Complementary therapies in medicine, 22(1), 57-62.

Gladding, S. T. (2016). The creative arts in counseling. Alexandria, VA - USA: American Counseling Association.

Gladding, S. T., Newsome, D., Binkley, E., \& Henderson, D. A. (2015). The lyrics of hurting and healing: Finding words that are revealing. Journal of Creativity in Mental Health, 3(3), 212-219.

Gómez Gallego, M., \& Gómez Garcia, J. (2017). Music therapy and Alzheimer's disease: Cognitive, psychological, and behavioural effects. Journal of Neurología. http://dx.doi.org/10.1016/j.nrl.2015.12.003

Gómez-Romero, M., Jiménez-Palomares, M., Rodríguez-Mansilla, J., Flores-Nieto, A., Garrido-Ardila, E.M., \& González-López-Arza, M. V. (2016). Benefits of music therapy on behaviour disorders insubjects diagnosed with dementia: A systematicreview. Journal of Neurología. http://dx.doi.org/10.1016/j.nrl.2014.11.001

Hui-Chi Li RN, Hsiu-Hung Wang RN, Fan-Hao Chou RN, \& Kuei-Min Chen RN. (2015). The effect of music therapy on cognitive functioning among older adults: A systematic review and meta-analysis. JAMDA The Society for Post-Acute and Long-Term Care Medicine, 16, 71-77. http://dx.doi.org/10.1016/j.jamda.2014.10.004

Laura, D., Sylvie, J., \& Aurore, S. (2015). The effects of music therapy on anxiety and depression. Ann Depress Anxiety, 2(4), 1057.

Mucci, K., \& Mucci, R. (2002). The healing sound of music. Findhorn Press.

Ottens, A. J. (1991). Coping with academic anxiety. New York: The Rosen Publishing Group. 
Purwanto, E. (2012). Pengelolaan kecemasan di kelas. In Prawitasari, J. E. (Ed.), Psikologi terapan: Melintas batas disiplin ilmu (p. 74-86). Jakarta: Erlangga.

Rogers, D. R. B., Sue Ei, Rogers, K. R., Cross, C. L. (2007). Evaluation of a multi-component approach to cognitive-behavioral therapy (CBT) using guided visualizations, cranial electrotherapy stimulation, and vibroacoustic sound. Complementary Therapies in Clinical Practice, 13, 95-101. http://dx.doi.org/10.1016/j.ctcp.2006.10.002

Rosanty, R. (2014). Pengaruh musik mozart dalam mengurangi stres pada mahasiswa yang sedang skripsi. Journal of Educational, Health and Community Psychology, 3(2),7178.

Schunk, D. H, Pintrich, P. R., \& Meece, J. L. (2014). Motivation in education: Theory, research and application ( $3^{\text {rd }}$ ed.). Pearson New International Edition.

Sharf, R. S. (2012). Theories of psychotherapy and counseling: Concepts and cases (5th ed.). California: Brooks/Cole.

Sharma, M., \& Jagdev, T. (2012). Use of music therapy for enhancing self-esteem among academically stressed adolescents. Pakistan Journal of Psychological Research, 27(1), 53.

Situmorang, D. D. B. (2005). Peranan musik bagi perkembangan panggilan para seminaris di Seminari Menengah Stella Maris Bogor (Unpublished seminarian's thesis). Seminari Menengah Stella Maris Bogor, Indonesia.

Situmorang, D. D. B. (2016). Hubungan antara potensi kreativitas dan motivasi berprestasi mahasiswa program studi bimbingan dan konseling angkatan 2010 FKIP Unika Atma Jaya.JBKI (Jurnal Bimbingan Konseling Indonesia), 1(1), 6-9. http://dx.doi.org/10.26737/jbki.v1i1.97

Situmorang, D. D. B. (2017a). Efektivitas pemberian layanan intervensi music therapy untuk mereduksi academic anxiety mahasiswa terhadap skripsi. JBKI (Jurnal Bimbingan Konseling Indonesia), 2(1), 4-8. http://dx.doi.org/10.26737/jbki.v2i1.242

Situmorang, D. D. B. (2017b). Mahasiswa mengalami academic anxiety terhadap skripsi? Berikan konseling cognitive behavior therapy dengan musik. Jurnal Bimbingan dan Konseling Ar-Rahman, 3(2), 31-42.

Situmorang, D. D. B. (2018a). Keefektifan konseling kelompok cognitive behavior therapy (CBT) dengan teknik passive dan active music therapy terhadap academic anxiety dan self-efficacy (Unpublished master's thesis). Program Pascasarjana Universitas Negeri Semarang, Indonesia.

Situmorang, D. D. B. (2018b). How amazing music therapy in counseling for millennials. COUNS-EDU: The International Journal of Counseling and Education, 3 (2). http://dx.doi.org/10.23916/0020180313220

Situmorang, D. D. B. (2018c). Music therapy bagi mahasiswa generasi millennials, perlukah? Buletin Psikologi, an accepted manuscript for publication on December 2018.

Situmorang, D. D. B., Mulawarman, M., Wibowo, M. E. (2018). Integrasi konseling kelompok cognitive behavior therapy dengan passive music therapy untuk mereduksi academic anxiety, efektifkah? Jurnal Kajian Bimbingan dan Konseling (JKBK), 3 (2), 49-58. https://doi.org/10.17977/um001v3i22018p049 
Skudrzyk, B., Zera, D. A., McMahon, G., Schmidt, R., Boyne, J., \& Spannaus, R. L. (2014). Learning to relate: Interweaving creative approaches in group counseling with adolescents. Journal of Creativity in Mental Health, 4(3), 249-261.

Spahn, C. (2015). Treatment and prevention of music performance anxiety. Progress in Brain Research, ISSN 0079-6123. http://dx.doi.org/10.1016/bs.pbr.2014.11.024

Stamoua V., Chatzoudi, T., Stamouc, L., Romod, L., \& Grazianie, P. (2016). Music-assisted systematic desensitization for the reduction of craving in response to drug-conditioned cues: a pilot study. The Arts in Psychotherapy, S0197-4556(15)30023-X. http://dx.doi.org/doi:10.1016/j.aip.2016.08.003

Sudarnoto, L. F. N., Pedhu, Y., Mamahit, H. C., \& Prasetiyo, T. D. (2012). Panduan penulisan skripsi. Jakarta: FKIP Unika Atma Jaya.

Vargas, M. E. R. (2015). Music as a resource to develop cognition. Procedia - Social and Behavioral Sciences, 174, 2989 - 2994.

Vianna, M. N. S., Barbosa, A. P., Carvalhaes, A. S., \& Cunha, A. J. L. A. (2012). Music therapy may increase breastfeeding rates among mothers of premature newborns: a randomized controlled trial. Voices: A World Forum for Music Therapy, 12(3).

Wigram, T., Pedersen, I. N., \& Bonde, L. O. (2002). A comprehensive guide to music therapy: Theory, clinical practice, research and training. London: Jessica Kingsley Publisher, Ltd.

Zarate, R. (2016). Clinical improvisation and its effect on anxiety: A multiple single subject design. The Arts in Psychotherapy, 48, 46-53.

Zarei, E., Fini, A. A. S., \& Khajehzadeh Fini, H. (2010). A comparison of effect of group counselling methods, behavioural, cognitive and cognitive-behavioural to reduce students: Test anxiety in the University of Hormozgan. Procedia-Social and Behavioral Sciences, 5, 2256-2261.

Zhang, Y., Jiayi Cai, Li An, Fuhai Hui, Tianshu Ren, Hongda Ma, \& Qingchun Zhao. (2017). Does music therapy enhance behavioral and cognitive function in elderly dementia patients? A systematic review and meta-analysis. Ageing Research Reviews, S15681637(16)30280-X. http://dx.doi.org/doi:10.1016/j.arr.2016.12.003

Copyright Holder:
C Situmorang, D. D. B. (2018)
First Publication Right :
C) Islamic Guidance and Counseling Journal

